\title{
Cooperative Learning to Train Children's Prosocial
}

\author{
Dema Yulianto ${ }^{1}$, Yufiarti ${ }^{2}$ and Ma'ruf $\mathrm{Akbar}^{3}$ \\ \{yulianto.dema@gmail.com,yufiarti@unj.ac.id and maruf@unj.ac.id\} \\ Universitas Negeri Jakarta, Indonesia ${ }^{123}$
}

\begin{abstract}
Childhood is a very fundamental phase in individual development. The independence of children is very important for their future growth, because of their orientation towards emotional and physical well-being, the ability to connect with each other and ethics. However, the prosocial behavior shown by children does not necessarily just happen but triggered by some sources. Therefore, this study was aimed at explaining the differences in prosocial behavior of students using picture and picture (PAP) and STAD cooperative learning based on the level of independence through the use of a quasi-experimental research method. The result of the study, however, showed that there are differences in prosocial behavior of students taught with PAP learning models and STAD. Further tests also confirmed a significant influence between the learning model and level of independence for student's prosocial behavior.
\end{abstract}

Keywords: cooperative learning, prosocial, early childhood

\section{Introduction}

In guiding children, there is a need to train and develop all their potentials, because every child has the right to grow and develop optimally. Children have their own world which is certainly different from the world of adults. Each of them has God-given intelligence and instincts as diverse creatures. Thus, it is very important to instill education in them from an early age in order to establish good social development. This helps them to know and understand their environment. Soodak stated that early childhood education helps real-life experience and assists children to understand their environment as they explore it. When children are taught through programs, they also learn a lot of academic and social skills such as cooperation, consideration for others, and working in groups ${ }^{1}$

One aspect of child development is the social development which involves the ability to behave in accordance with the social environment. One important thing that distinguishes humans from other creatures is the degree of mutual help, cooperation and caring amongst them. ${ }^{2}$ Prosocial behavior displayed in people's life is developed from an early age and introduced by parents, who are their main educators, at home.

Early age is the most appropriate time to introduce, grow and develop prosocial attitudes. According to Johnson, preschool is a sensitive period for the development of prosocial skills with 
little attention being placed on the processes that hinder and encourages it during this period. Clearly, child adaptive socialization model is believed to be contributing significantly to this development. ${ }^{3}$

By educating them at the early stage of their childhood, children will have quality in their future but it is not easy to understand the method or way of providing the education so that they continue to enjoy and improve their creativity. Therefore, effective learning is needed to support their development. However, cooperative learning is a learning method where students cooperate in small groups to learn in a psychomotor, cognitive, and affective way. ${ }^{4}$ It is characterized by various forms of interaction through physical activity. ${ }^{5}$ Some works of research have been done on cooperative learning as regards its capacity to increase physical activity, skills, and problemsolving abilities

According to Visek A.J. et al., ${ }^{6}$ the concept of mapping is used in providing evidence-based print images for the theory of pleasure integration which is applied in maximizing pleasure for children. In line with this submission, picture model and picture (PAP) is defined as a learning model that uses picture media in its implementation. This is necessary for making students more interested and motivated in learning activities because with this model, they do not only write, listen, and ask, but also see and explain what is being taught in accordance with their understanding. It is also useful in ensuring that children learn pictorially rather than abstractly, thereby, making the learning atmosphere active, interesting and exciting which subsequently motivate them to cooperate, care for each other and help one another.

In addition, another model that can also be implemented in social-emotional education is the STAD method (Student Teams Achievement Divisions). This learning approach focuses on the collaboration of small groups of students to maximize learning conditions in order to achieve learning goals. It involves positive interdependence, face-to-face interactions, individual accountability, and skills for interpersonal relationships or deliberately taught social skills. Therefore, this study was conducted to analyze the effect of interaction between cooperative learning and independence on children's prosocial behavior.

\section{Research Location}

This research was conducted in two kindergarten schools in Ngasem District, Kediri Regency in East Java Province.

\section{Methods}

An experimental method of research was used in explaining the differences in prosocial behavior of students such as the role of cooperative learning and independence for early childhood prosocial behavior. This was conducted using experimental design by level $(2 \times 2)$. A sample of 48 students was obtained from the schools using Multistage Random Sampling techniques. 
The research treatment consisted of cooperative learning using the PAP type learning approach in one group and the STAD in another. However, prosocial behavior was measured by sharing, cooperation, helping, giving and honesty. Independence by physical ability, confidence, responsibility, discipline, cleverness, sharing, and controlling emotions while the cooperative learning was measured based on two approaches of Picture and Picture (PAP) and Student Teams Achievement Divisions (STAD) learning types.The results of this research can be seen on the link (https://osf.io/5y6x8/)

\section{Results Discussion}

Normality test data and homogeneity test were used in analyzing the research data while the research hypothesis tested for the difference between Picture and Picture (PAP) and Student Teams Achievement Divisions (STAD) on early childhood prosocial behavior considering the independence and interaction between the two factors.

This research made use of a two-factor ANOVA design or factorial $2 \times 2$ where the independent variables were limited to high and low respectively after which another test was conducted on their effect on prosocial behavior of early childhood in kindergarten. The hypothesis was tested using ANOVA while further tests were conducted using the Tukey Test as shown in the table below:

Table 1. Results of Calculation of two-factor ANOVA ( 2 x 2)

\begin{tabular}{|c|c|c|c|c|c|c|}
\hline \multirow{2}{*}{ Variant source } & \multirow{2}{*}{$\mathrm{JK}$} & \multirow{2}{*}{$\mathrm{Dk}$} & \multirow{2}{*}{ RJK } & \multirow{2}{*}{$\mathrm{F}_{\text {count }}$} & \multicolumn{2}{|c|}{$\mathrm{F}_{\text {table }}$} \\
\hline & & & & & 0,05 & 0,01 \\
\hline Inter column & 1 & 44,08 & 44,08 & $6,549^{*}$ & 4,06 & 7,25 \\
\hline Inter line & 1 & 40,33 & 40,33 & $5,992^{*}$ & 4,06 & 7,25 \\
\hline Interaction & 1 & 1121,33 & 1121,33 & $166,591^{* *}$ & 4,06 & 7,25 \\
\hline In & 44 & 296,17 & 6,73 & & & \\
\hline Totally reduction & 47 & 1501,92 & & & & \\
\hline
\end{tabular}

The results of the analysis showed that there was an interaction between cooperative learning and independence towards early childhood prosocial behavior. This was founded on the fact that Fcount $(166,591)$ is greater than Ftable (0.05) (4.06). Cooperative learning models are developed to achieve learning outcomes in the form of academic achievement, tolerance, accepting diversity and developing social skills. The main principle behind this is to make children more responsible individually or in groups while the goal is to make them learn in groups by respecting opinions and providing opportunities for others to express their ideas. 
The environment is a very decisive factor in achieving preschooler's independence. A good environment increases the quick achievement of children's independence. Cooperative learning creates certain characteristics in a child's personality that affect his or her independence. Therefore, it produces independent children that can control themselves, maintain good relationships with friends, able to deal with stress, interested in new things, and cooperative with others. These results are supported by Huang when he stated that cooperative learning is the application of social skills such as face-to-face interactions and other physical activities in improving problem-solving skills.

In addition, cooperative learning can also be applied to support independence and socialemotional education where the learning approach focuses on using small groups of students to collaborate in maximizing learning conditions in order to be independent and interact socially.

\section{Conclusion}

Prosocial behavior influences children's cognitive development. ${ }^{7}$ At the early childhood, it can be determined by independence observable from the ability of children to carry out their own activities or able to stand alone in every condition from simple tasks such as taking care of themselves to complex ones like understanding their own needs. Furthermore, in the school age, learning methods have a direct influence on children's prosocial attitudes. Therefore, the right learning method in forming children's prosocial attitudes is cooperative learning because it embodies student-centered teaching and learning activities, especially by helping the ones that have problems working with others, aggressive and the ones that do not care about others.

\section{References}

[1] Soodak, C. Leslle, et. al.,: Implementing Inclusive Early Childhood Education: A Call for Professional Empowerment, TECSE, p.91-102 (2002,)

[2] Knafo\&Polmin. "Prosocial Behavior From Early to Middle Childhood: Genetic and Environmental Influences on Stability and Change". Journal of Developmental Psychology. 42, (5), 771-786, p.1 (2006)

[3] Johnson, Stacy R. et.al: Can classroom emotional support enhance prosocial development among children with depressed caregivers?, Early childhood Research Quarterly 28, 282290(2013)

[4] Iserbyt, P., Madou, B., Vergauwen, L., \&Behets, D. :Effects of peer mediated instruction with task cards on motor skill acquisition in tennis. Journalof Teaching in Physical Education, 30, 31-50(2011)

[5] Barrett, T. :Effects of cooperative learning on the performance of sixth-grade physical education students. Journal of Teaching in Physical Education, 24, 88-102 (2005)

[6] Visek, A. J., Achrati, S. M., Manning, H., McDonnell, K., Harris, B. S., \&DiPietro, L. :The fun integration Theory: Towards sustaining children andadolescents sport participation. Journal of Physical Activity and Health, 12(3), 424-433(2015) 
[7] Huang, et.all., :Effects of cooperative learning and concept mappingintervention on critical thinking and basketball skills inelementary School, Thinking Skills and Creativity 23 Journal, p. 207-216 (2017) 